\title{
COMPARING SHEAR-WAVE VELOCITY DETERMINED BY MASW WITH BOREHOLE MEASUREMENT AT MERAPI SEDIMENT IN YOGYAKARTA
}

\author{
Widjojo A. Prakoso ${ }^{1}$, Astri Rahayu ${ }^{1,2 *}$, Imam A. Sadisun ${ }^{3}$, Agus S. Muntohar ${ }^{4}$, M. Muzli ${ }^{5}$, \\ Ariska Rudyanto ${ }^{5}$ \\ ${ }^{1}$ Department of Civil Engineering, Faculty of Engineering, Universitas Indonesia, Kampus UI Depok, \\ Depok 16424, Indonesia \\ ${ }^{2}$ Department of Civil Engineering, Faculty of Engineering, Universitas Tadulako, Kampus Bumi \\ Tadulako, Palu 94118, Indonesia \\ ${ }^{3}$ Faculty of Civil and Environmental Engineering, Institut Teknologi Bandung, Jl. Ganesha 10, \\ Bandung, Indonesia \\ ${ }^{4}$ Department of Civil Engineering, Faculty of Engineering, Universitas Muhammadiyah Yogyakarta, \\ Kampus UMY 55183, Yogyakarta, Indonesia \\ ${ }^{5}$ Meteorological, Climatological, and Geophysical Agency (BMKG), Jl. Angkasa I No. 2 Kemayoran, \\ Jakarta Pusat 10720, Indonesia
}

(Received: January 2017 / Revised: June 2017 / Accepted: December 2017)

\begin{abstract}
Next generation ground motion prediction models use shear-wave velocity over the top $30 \mathrm{~m}$ of subsoil $\left(\mathrm{V}_{\mathrm{S} 30}\right)$ as an important assessment parameter of seismic ground surface motion. $\mathrm{V}_{\mathrm{S} 30}$ can be measured using invasive methods, such as boreholes, or non-invasive methods, such as multichannel analysis of surface waves (MASW). To evaluate this technique in a variety of near-surface conditions, MASW-derived shear-wave velocity profiles (s-wave velocity vs. depth) were statistically compared to direct borehole measurements from three locations of Merapi sediment found on the Universitas Muhammadiyah Yogyakarta (UMY) campus site. A detailed study of the effect from the total number of recording channels of MASW, sampling intervals, source offset, and receiver spacing was conducted near the borehole test site. The soil was classified as a medium soil or SD. The MASW method, which is non-destructive and noninvasive in nature and relatively faster in assessment, provides more reliable shear-wave velocity profiles, i.e. from 0 to 30 meters below the ground surface.
\end{abstract}

Keywords: MASW; Merapi sediment; Shear-wave velocity; $\mathrm{V}_{\mathrm{S} 30}$

\section{INTRODUCTION}

In Indonesia, there are numerous earthquakes with magnitudes greater than five. Two severe earthquakes occurred in Aceh (December $\left.26^{\text {th }}, 2004\right)$ followed by a tsunami $(\mathrm{Mw}=9.2)$ and the Yogyakarta earthquake (May $\left.27^{\text {th }}, 2006\right)(\mathrm{Mw}=6.3)$. The former caused more than a hundred thousand deaths, while the latter resulted in severe damage to thousands of infrastructures and buildings. Rehabilitation and reconstruction to repair this damage cost trillions of rupiahs (Irsyam et al., 2010). To reduce disaster risk due to earthquakes, the government of Indonesia replaced the SNI 1726-2002 standard with a new standard, SNI 1726-2012. This latest standard takes into account the procedures used to design building and non-building structures so that they are able to withstand earthquakes. During an earthquake event, seismic waves travel from

\footnotetext{
*Corresponding author's email: astri_rahayum@yahoo.com, Tel: +62-21-7270029, Fax: +62-21-7270029 Permalink/DOI: https://doi.org/10.14716/ijtech.v8i6.744
} 
the epicenter up to the ground surface, undergoing a process of amplification or deamplification. The process depends on the earthquake's magnitude and the soil conditions.

In SNI 1726-2012, the soil conditions are represented by the site class system, which depends on-among other factors - the shear-wave velocity over the top $30 \mathrm{~m}$ of subsoil $\left(\mathrm{V}_{\mathrm{S} 30}\right)$ direct measurement, as seen in Table 1 (BSN, 2012). The $\mathrm{V}_{\mathrm{S} 30}$ is used as a parameter of seismic ground surface motion. Site-invasive methods commonly used for obtaining the $\mathrm{V}_{\mathrm{S} 30}$ are crosshole, down-hole, up-hole, and PS suspension logging. These seismic tests are expensive and impose time constrains, therefore a robust approach to mitigate such issues is needed (Kitsunezaki, 1980). Geophysical methods are non-invasive and non-destructive in nature with relatively fast in assessment by using surface waves to examine the soil stiffness profile and shear-wave velocity, which is the best seismic parameters.

Table 1 Soil classification in SNI 1726-2012 (BSN, 2012)

\begin{tabular}{lcc}
\hline \multicolumn{1}{c}{ Site Class } & $\mathrm{V}_{\mathrm{s} 30}(\mathrm{~m} / \mathrm{s})$ & N-SPT (blow/0.3m) \\
\hline SA (hard rock) & $>1500$ & Not Available \\
SB (rock) & $750-1500$ & Not Available \\
SC (hard soil, dense and soft rock) & $350-750$ & $>50$ \\
SD (medium soil) & $175-350$ & $15-50$ \\
SE (soft soil) & $<175$ & $<15$ \\
SF (special soil) & Soil profile with more than 3 soil \\
& characteristics: plasticity index, PI $>20 ;$ \\
& water content, w $\geq 40 \%$; and unconfined \\
& shear strength, su < 25 \\
\hline
\end{tabular}

The active multichannel analysis of surface wave (MASW) method was developed from the microtremor survey method, which originated in Japan. The microtremor method uses passive surface waves generated from natural (e.g., tidal motion) or cultural (e.g., traffic) sources. The active MASW method utilizes the dispersion properties of surface waves. Frequencies of a few to a few tens of $\mathrm{Hz}$ (e.g., 3-30 Hz) produced from active impact sources, such as sledge hammers, are then recorded by a multichannel recording system and a receiver array. The investigation depth is about $30 \mathrm{~m}$. The MASW procedure usually consists of three steps: acquiring multi-channel field records (or shot gathering), extracting dispersion curves, and finally inverting the dispersion curves to obtain 1-D or 2-D V $\mathrm{V}_{\mathrm{S} 30}$ and depth profiles (Park et al., 2007).

The Standard Penetration Test (N-SPT; ASTM, D1586) is one of the oldest and most widely used in-situ tests worldwide, and is classified as an invasive and expensive test. N-SPT index values for formation hardness or stiffness used in soil mechanics and foundation engineering can correspond to shear-wave velocity (Knappett \& Craig, 2012). This phenomenon has attracted interest in many groundwater engineering, seismotectonic engineering, and environmental studies.

The main objective of this research is to determine the $V_{S 30}$ of quaternary sand deposit based on the MASW technique and validating the measurements by borehole SPT data. Lesson study on the quaternary sand deposit. Hence, this study needs to apply the investigation using MASW. The quaternary sand deposit is a Merapi sediment which is found on the Universitas Muhammadiyah Yogyakarta (UMY) campus site. The location was high risk to the liquefaction (Muntohar, 2012). The study location consisted of Quaternary Merapi sediment as shown in Figure-1. Mainly, the area is covered by sand deposit. 


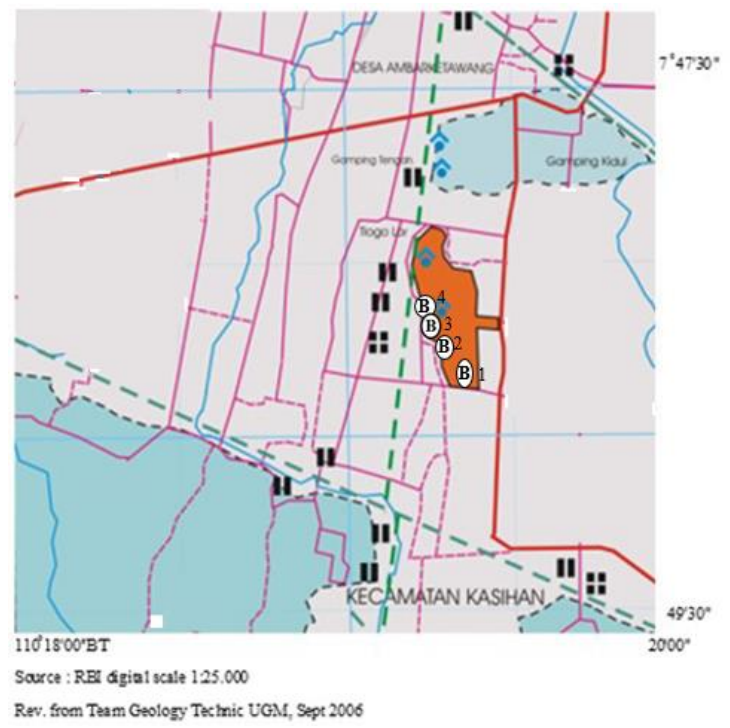

GEOLOGY MAP

GAMPING AREA

YOGYAKARTA

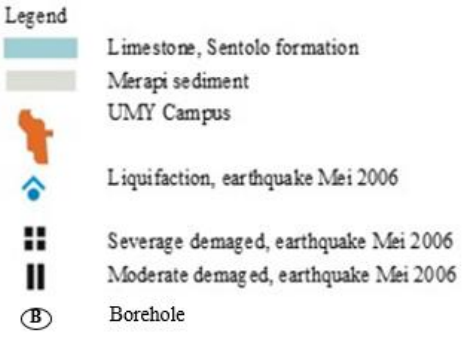

Figure 1 Test location at Universitas Muhammadiyah Yogyakarta

(Source RBI, processed by Dept. Geology Eng. UGM, 2006)

\section{METHODOLOGY}

The $\mathrm{V}_{\text {S30 }}$ measurement was carried out as a field survey using the MASW method.

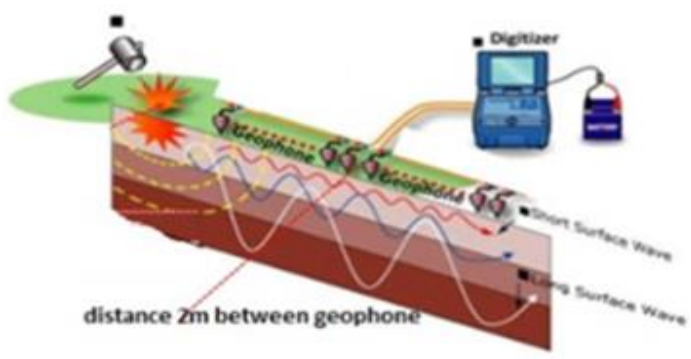

a. MASW equipment

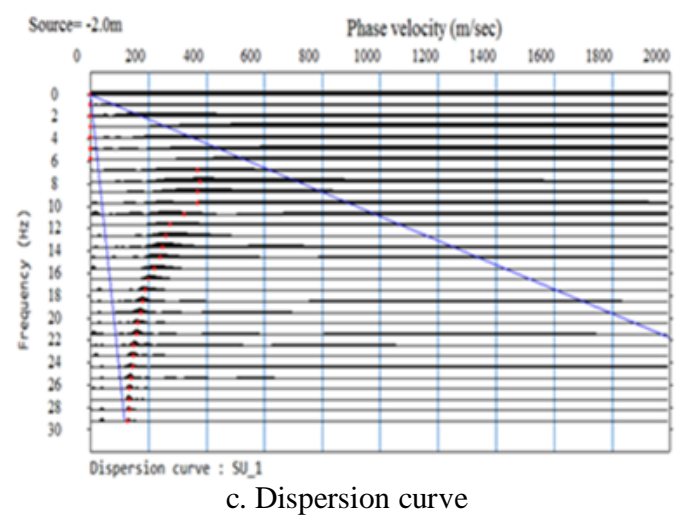

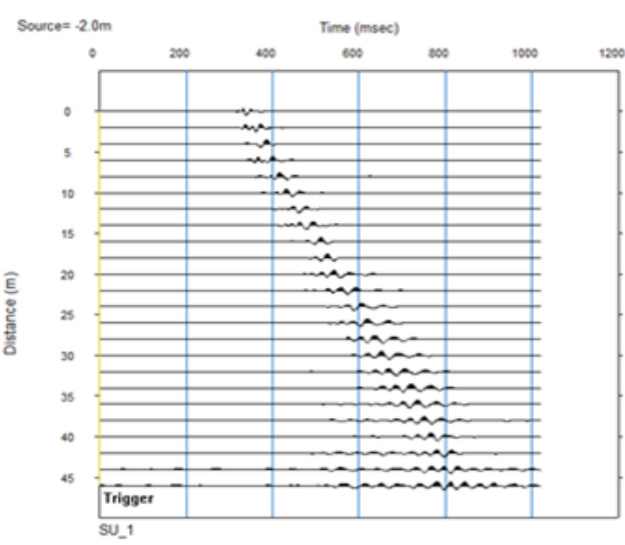

b. Multichannel raw field data

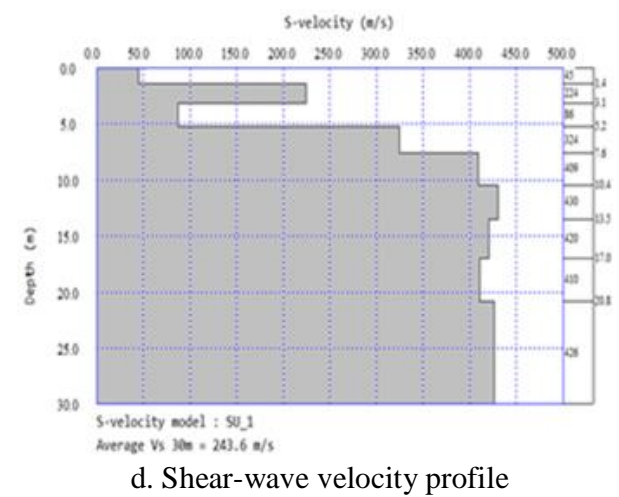

Figure 2 A diagram of the MASW method: (a) MASW equipment; (b) raw field data, which contain enhanced ground roll signals, are acquired; (c) Rayleigh wave dispersion in the frequency-phase velocity domain; and (d) shear-wave velocity to depth profile 
In this study, the MASW measurements were performed nearby the boreholes as indicated in Figure 1. The common in situ geotechnical parameter, N-SPT, from boreholes is used as it has an empirical relationship to $\mathrm{V}_{\mathrm{S} 30}$. The principle of the MASW survey is based on the theory of propagation of Rayleigh surface waves, in which a surge is produced by the interaction of waves propagating within a layer of soil. The $\mathrm{V}_{\mathrm{S} 30}$ profile was subsequently determined by measuring the speed of the arrival times of the surface waves. Figure 2 shows a diagram of the MASW method (Park et al., 2007).

- The $\mathrm{V}_{\mathrm{S} 30}$ was measured using OYO 24 Channel McSeis-SXW seismic refraction equipment in one dimension.

- The measurements were performed in 2015 by a joint research team consisting of the civil engineering team from Universitas Indonesia, the seismotectonic group from the Indonesian Agency for Meteorology, Climatology, and Geophysics, and the civil engineering team from Universitas Muhammadiyah Yogyakarta.

- The measurement was performed near Borehole 2, Borehole 3, and Borehole 4 on the UMY campus site. Due to the space requirement of lengths of about 50 meters, the measurement could not be performed in borehole 1 .

- Data from the MASW were subsequently processed using the SeisImager Program; the process is illustrated in Figures $2 \mathrm{a}, 2 \mathrm{~b}, 2 \mathrm{c}$, and $2 \mathrm{~d}$.

\subsection{Standard Penetration Test}

Standard Penetration Test (ASTM, 2008, D1586) data were collected in 2006 by Muntohar (2010). The N-SPT value from borehole data was used to estimate shear-wave velocity in empirical conversion. Several correlations are available for $\mathrm{V}_{\mathrm{S}}$ values from $\mathrm{N}-\mathrm{SPT}$ from various countries:

$$
\begin{aligned}
& V_{S}=87.8 \mathrm{~N}^{0.292}, \text { for alluvial sands (Japan) } \\
& V_{S}=110.0 \mathrm{~N}^{0.285}, \text { for diluvial sands (Japan), (Imai \& Tonouchi,1982 in Sykora, 1987) } \\
& V_{S}=100.6 \mathrm{~N}^{0.290}, \text { for sandy soils (US), (Sykora \& Stokoe, } 1983 \text { in Sykora, 1987) } \\
& V_{S}=104.7 \mathrm{~N}^{0.296}, \text { for SM soils (Taipei Basin, Taiwan), (Lee, 1992) } \\
& V_{S}=90.8 \mathrm{~N}^{0.319}, \text { for sands (Yenisehir, Turkey), (Hasancebi \& Ulusay, 2007) } \\
& V_{S}=79.0 \mathrm{~N}^{0.434}, \text { for sands (Delhi, India), (Hanumantharao \& Ramana, 2008) } \\
& V_{S}=82.0 \mathrm{~N}^{0.319}, \text { for alluvial soils (sands-silts) (Korea) } \\
& V_{S}=75.8 \mathrm{~N}^{0.371}, \text { for weathered residual soils/sands (Korea) } \\
& V_{S}=107.9 \mathrm{~N}^{0.418}, \text { for weathered rocks (Korea), (Sun et al., 2008) } \\
& V_{S}=77.0 \mathrm{~N}^{0.330}, \text { for sands (Erbaa, Turkey), (Dikmen, 2009) } \\
& V_{S}=79.7 \mathrm{~N}^{0.365}, \text { for sands (Greece), (Tsiambaos \& Sabatakakis, 2011) } \\
& V_{S}=104.6 \mathrm{~N}^{0.330}, \text { for structured soil deposits (Molise, Italy), (Fabbrocino et al., 2015) } \\
& V_{S}=100.3 \mathrm{~N}^{0.365}, \text { for sands (Roorkee, India), (Kirar et al., 2016) }
\end{aligned}
$$

Table 2 shows the N-SPT values of the three boreholes. Equations 1 to 13 were used to empirically convert $\mathrm{V}_{\mathrm{S}}$ to N-SPT. 
Table 2 N-SPTs in the three boreholes

\begin{tabular}{cccc}
\hline \multirow{2}{*}{ Depth $(\mathrm{m})$} & Borehole 2 & Borehole 3 & Borehole 4 \\
\cline { 2 - 4 } & N-SPT & N-SPT & N-SPT \\
\hline 2.00 & 32 & 28 & 27 \\
3.50 & 17 & 31 & 29 \\
5.00 & 38 & 23 & 32 \\
6.50 & 20 & 25 & 21 \\
8.00 & 22 & 60 & 23 \\
9.50 & 26 & 60 & 26 \\
11.00 & 29 & 27 & 30 \\
12.50 & 24 & 39 & 36 \\
14.00 & 27 & 28 & 10 \\
15.50 & 55 & 23 & 28 \\
17.00 & 25 & 8 & 60 \\
18.50 & 11 & 35 & 33 \\
20.00 & 60 & 30 & 35 \\
21.50 & 48 & 32 & 31 \\
23.00 & 60 & 34 & 34 \\
24.50 & 60 & 25 & 57 \\
26.00 & 37 & 28 & 60 \\
27.50 & 28 & 22 & 32 \\
29.00 & 25 & 25 & 36 \\
30.50 & 23 & 27 & 60 \\
\hline
\end{tabular}

Source: Soil Mech. Lab., UMY investigation report, 2006

\section{RESULTS AND DISCUSSION}

Shear-wave velocity to depth diagrams from the MASW measurements with empirical conversions of Vs to N-SPT using Equations 1 to 13 are shown in Figures 3a, 3b, and 3c.

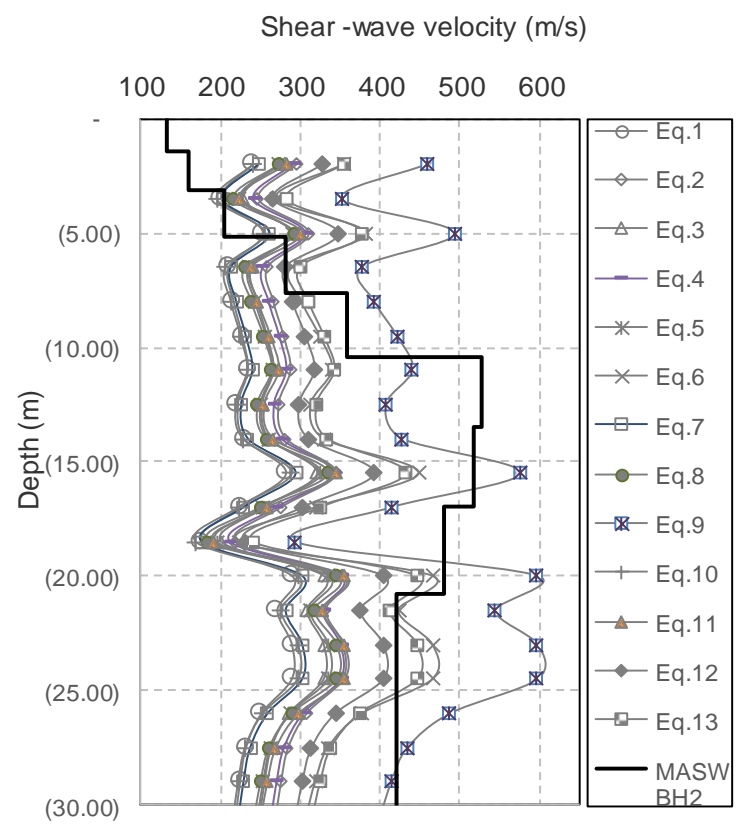

Figure 3 (a) Shear-wave velocity to depth from MASW and empirical velocity from Borehole 2

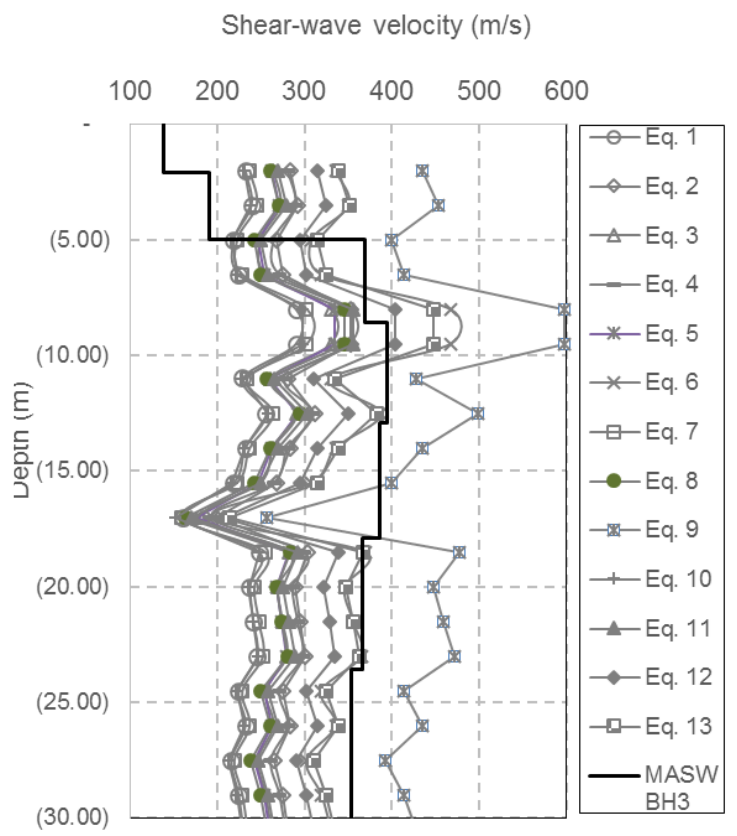

Figure 3 (b) Shear-wave velocity to depth from MASW and empirical velocity from Borehole 3 


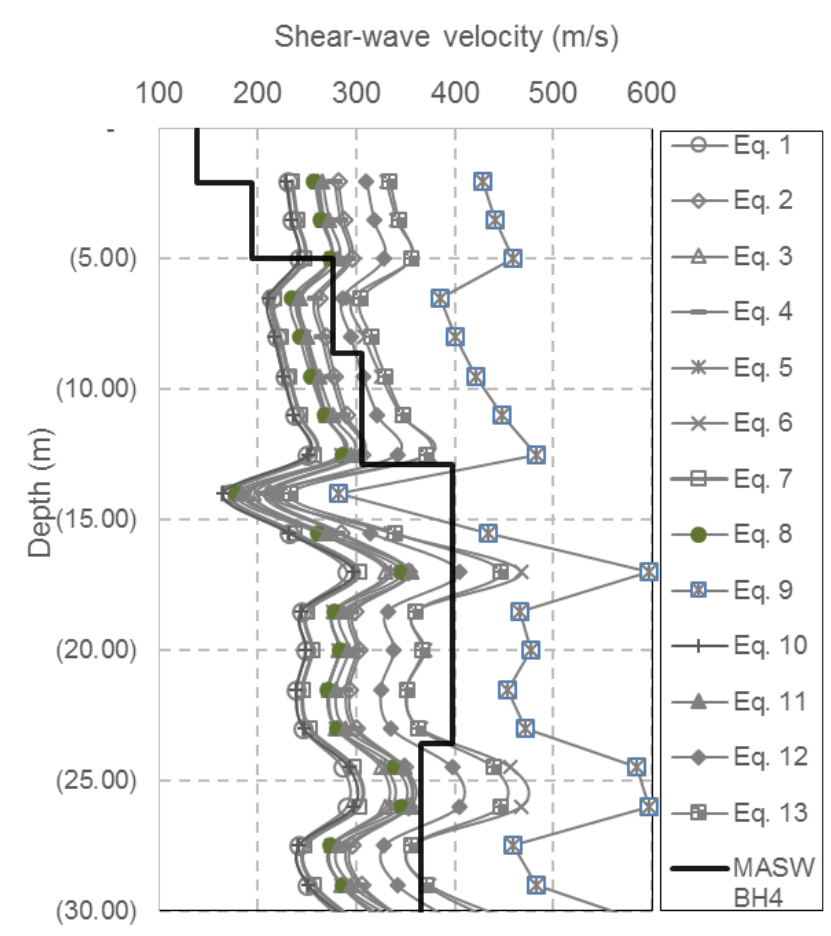

Figure 3 (c) Shear-wave velocity to depth from MASW and empirical velocity from Borehole 4

Figures $3 \mathrm{a}, 3 \mathrm{~b}$, and $3 \mathrm{c}$ show that all empirical conversions of N-SPT resulted in different shearwave velocity values. Equations 1 to 13 represent conversions from all over the world. As soil is nonhomogenous, most correlations published are valid only for the specific site. Madun et al. (2016) converted N-SPT values to shear-wave velocity based on Tsiambaos and Sabatakakis (2011) equation Vs $=105.70 \mathrm{~N}^{0,327}$ for all types of soil. Prakoso (2011) correlated shear-wave velocity from N-SPT with the seismic downhole test. Marto et al. (2013) proposed a correlation of N-SPT to Vs that is applicable to all types of soil. However, this research using equations is specific for sandy soil.

The conversion formulas that are commonly used (e.g., Equations 1, 2, and 3) have lower Vs values than those obtained in MASW direct measurements. The results of shear-wave velocity from N-SPT conversions are lower than MASW direct measurements. Additionally, layers in MASW graphs are thicker than those in SPT.

The MASW direct measurements in Figures 3a, 3b, and 3c show that the average Vs values from the three sites are $175-350 \mathrm{~m} / \mathrm{s}$. Therefore, according to Table 1, the soil was classified as a medium soil or SD. The inverted velocity range is shown in Table 3.

It was found that out of all the Equations 6 and 13 are closest to the MASW direct measurements. This means that the type of sand in the measurement area has a value of exponent $\mathrm{N}$, compatible with those equations. Moreover, a comparison of the significant layers was generated. The results are represented in the form of average relative differences in all layers of soil. The average relative difference describes the overall differences between shearwave velocities from the MASW method and the empirical borehole method (Xia et al., 2000). These results are shown in Table 3. 
Table 3 Comparison of the shear-wave velocities from the MASW method and the borehole results

\begin{tabular}{|c|c|c|c|c|c|c|}
\hline \multirow[t]{2}{*}{$\begin{array}{l}\text { Borehole } \\
\text { ID }\end{array}$} & $\begin{array}{c}\text { Average } \\
\text { difference }(\mathrm{m} / \mathrm{s})\end{array}$ & $\begin{array}{l}\text { Maximum relative } \\
\text { difference }(\%)\end{array}$ & $\begin{array}{l}\text { Average } \\
\text { relative } \\
\text { difference } \\
\quad(\%)\end{array}$ & $\begin{array}{l}\text { Standard } \\
\text { deviation } \\
(\mathrm{m} / \mathrm{s})(\%)\end{array}$ & \multirow{2}{*}{$\begin{array}{l}\text { Depth } \\
\text { studied } \\
\text { by } \\
\text { MASW } \\
\text { (m) }\end{array}$} & \multirow[t]{2}{*}{$\begin{array}{l}\text { Inverted } \\
\text { velocity } \\
\text { range } \\
(\mathrm{m} / \mathrm{s})\end{array}$} \\
\hline & Eqs. 6 and 13 & Eqs. 6 and 13 & Eqs. 6 and 13 & Eqs. 6 and 13 & & \\
\hline Borehole 2 & $101.34 ; 95.00$ & $115.64 ; 93.10$ at $17 \mathrm{~m}$ & $32.19 ; 28.39$ & $29.32 ; 25.56$ & 30 & $132-529$ \\
\hline Borehole 3 & $127.85 ; 127.63$ & $103.80 ; c$ & $39.55 ; 37.10$ & 9.11 & 30 & $39-395$ \\
\hline Borehole 4 & $71.17 ; 73.18$ & $86.32 ; 65.78$ at $14 \mathrm{~m}$ & $21.12 ; 20.59$ & $20.80 ; 18.26$ & 30 & $138-398$ \\
\hline \multicolumn{7}{|c|}{$\begin{array}{c}\text { Terminology used in this table: } 1 \text {. Average difference }=(1 / \mathrm{n}) \sum|\mathrm{Vb}-\mathrm{Vi}| \text {, where } \mathrm{Vb} \text { represents the s-wave } \\
\text { velocities from the borehole measurements, } \mathrm{Vi} \text { is the s-wave velocity inverted from the Rayleigh wave phase } \\
\text { velocity, } \mathrm{n} \text { is the number of layers; } 2 \text {. The maximum relative difference } \mathrm{R}=100 * \mathrm{D} /(\mathrm{Vb}) \mathrm{k} ; 3 \text {. Average relative } \\
\text { difference } \overline{\mathbb{R}}=(100 / \mathrm{n}) \sum(|\mathrm{Vb}-\mathrm{Vi}| / \mathrm{Vb}) \mathrm{k} .\end{array}$} \\
\hline
\end{tabular}

Table 3 shows that the average relative difference is greater than $20 \%$, indicating fair agreement. Excellent agreement is deemed to have been obtained if the result is around 10\% and the agreement is described as good in velocity profiles when a major difference exists in only one layer.

\section{CONCLUSION}

According to the average shear-wave velocity, the MASW direct measurement method classifies the Merapi sediment on the UMY Campus as a medium soil. The soil profile of shearwave velocity from the MASW direct measurement moderately deviates as compared with empirical conversion using N-SPT values. The MASW method is a non-invasive approach to estimate near surface shear-wave velocity and has the potential to substitute more invasive and destructive tests. As the use of MASW is less expensive than SPT, further bore data sharing is needed to develop empirical conversions of N-SPT appropriate to the type of soil in Indonesia.

\section{ACKNOWLEDGEMENT}

The authors gratefully acknowledge the research grant PUPT No. 2766/UN2.R3.1/HKPO5.00/2017 provided by Kemenristekdikti for budget year 2017.

\section{REFERENCES}

American Society for Testing and Materials (ASTM), 2008. Standard Test Method for Penetration Test and Split Barrel Sampling of Soils (D1586). Philadelphia: Annual Book of Standards, Volume 4(8), ASTM

Badan Standarisasi Nasional (BSN), 2012. Tata Cara Perencanaan Ketahanan Gempa untuk Struktur Bangunan Gedung dan Non Gedung (Indonesia Seismic Building Code). Jakarta, Indonesia

Dikmen, Ü., 2009. Statistical Correlation of Shear Wave Velocity and Penetration Resistance for Soils. Journal of Geophysics and Engineering, Volume 6, pp. 61-72

Fabbrocino, S., Lanzano, G., Forte, G., de Magistris, F.S., Fabbrocino, G., 2015. SPT Blow Count vs. Shear Wave Velocity Relationship in the Structurally Complex Formation of the Molise Region (Italy). Engineering Geology, Volume 187, pp. 84-97

Hanumantharao, C., Ramana, G.V., 2008. Dynamic Soil Properties for Microzonation of Delhi, India. Journal Earth System Science, Volume 117(S2), pp. 719-730

Hasancebi, N., Ulusay, R., 2007. Empirical Correlations between Shear-wave Velocity and Penetration Resistance for Ground Shaking Assessments. Bulletin of Engineering Geology and Environmental, Volume 66, pp. 203-213 
Irsyam, M., Sengara, I.W., Aldiamar, F., Widiyantoro, S., Triyoso, W., Hilman, D., Kertapati, E., Meilano, I., Suhardjono, Asrurifak, M., Ridwan, M., 2010. Summary Report of Revision of Seismic Hazard Map on Indonesia 2010. Bandung, Indonesia

Kirar, B., Maheshwari, B.K., Muley, P., 2016. Correlation between Shear Wave Velocity (Vs) and SPT Resistance (N) for Roorkee Region. International Journal of Geosynthetics and Ground Engineering, Volume 2(1), pp. 1-11

Kitsunezaki, C., 1980. A New Method for Shear-wave Logging. Geophysics, Volume 45(10), pp. 1489-1506

Knappett, J.A., Craig, R.F., 2012. Craig's Soil Mechanics, $8^{\text {th }}$ ed. London and New York: Spon Press

Lee, S.H.H., 1992. Analysis of the Multicolinearity of Regression Equations of the Shear Wave Velocities, Soils and Foundations, Volume 32(1), pp. 205-214

Madun, A., Supa'at, M.E.A., Tajudin, S.A.A., Zainalabidin, M.H., Sani, S., Yusof, M.F., 2016. Soil Investigation using Multichannel Analysis of Surface Waves (MASW) and Boreholes. ARPN Journal of Engineering and Applied Sciences, Volume 11, pp. 3759-3763

Marto, A., Soon, T.C., Kasim, F., Suhatril, M., 2013. A Correlation of Shear Wave Velocity and Standard Penetration Resistance. Electronic Journal of Geotechnical Engineering, Volume 18(C), pp. 463-471

Muntohar, A.S., 2010. Microzonation of Liquefaction Potential and Ground Settlement-induced by Earthquake. Research Report, Universitas Muhammadiyah Yogyakarta (in Bahasa)

Muntohar, A.S., 2012, Parametric Study of the Liquefaction Potential and Ground Settlement Using CPT. In: the $16^{\text {th }}$ Annual Scientific Conference of the Indonesian Society for Geotechnical Engineering, Jakarta, 4-5 Desember 2012, pp. 139-144 (in Bahasa)

Park, C.B., Miller, R.D., Xia, J., 2007. Multichannel Analysis of Surface Waves (MASW) Active and Passive Methods. The Leading Edge, January 2007, pp. 60-64

Prakoso, W.A., 2011. Shear-wave Velocity of Cemented Soils of Jakarta (Technical Notes), Jurnal Teknik Sipil, Volume 18(3), December 2011, pp. 301-307

Tsiambaos, G., Sabatakakis, N., 2011. Empirical Estimation of Shear-wave Velocity from In Situ Tests on Soil Formation in Greece. Bulletin of Engineering Geology and Environment, Volume 70, pp. 291-297

Sun, C-G., Kim, H-J., Chung, C-K., 2008. Deduction of Correlation between Shear Wave Velocity and Geotechnical In-situ Penetration Test Data. Journal of the Earthquake Engineering Society of Korea, Volume 12(4), pp. 1-10

Sykora, D.W., 1987. Examination of Existing Shear Wave Velocity and Shear Modulus Correlation in Soil, Vicksburg, Miss.: U.S. Army Engineer Waterways Experiment Station, Ed : National government publication

Xia, J., Miller, R.D., Park, C.B., Hunter, J.A., Harris, J.B., 2000. Comparing Shear-wave Velocity Profiles from MASW with Borehole Measurement in Unconsolidated Sediment, Fraser River Delta, B.C., Canada. Journal of Environmental and Engineering Geophysics, Volume 5(3), pp. 1-13 